\title{
Reflection on Improving Personnel Development of Applied Psychology
}

\author{
Specialty \\ Xingjuan Liu \\ College of humanities, Jilin Agricultural University, Changchun, 130118, Jilin, China \\ xingzi1980@126.com
}

Keywords: Personnel development, Applied psychology specialty, Reflection

\begin{abstract}
The personnel development of applied psychology specialty in university is a difficult task. We paid much attention with the professional development as following aspects: goal orientation, faculty capacity building, graduation project design. According to goal of personnel of multiple skills, the construction of curriculum, teachers' team, professional practice teaching should be reflected and considered.
\end{abstract}

\section{Introduction}

The department of applied psychology in Jilin Agricultural University was founded in 2003. We are trying to explore a unique way to the development of applied psychology specialty during thirteen years. We made some remarkable achievements in the process of specialty construction, we have 4 laboratories now, they are basic psychological laboratory, psychological measurement and evaluation laboratory, mental health and psychological counseling laboratory, laboratory of developmental psychology, which can basically meet the needs of teaching. Over the thirteen years, more than 600 students graduated from here. After graduation, some students were admitted to Northeast Normal University, Jilin University, Southwestern University and other famous universities.

But we are very clear that applied psychology specialty is a very young vulnerable specialty in an agricultural university, compared to other professional psychology specialty in other universities, we have many deficiencies, such as the laboratory construction is seriously lagging behind and weak practical teaching, the curriculum is not reasonable and outdated teaching methods, teachers and teachers' lack of practical ability [1]. The professional teachers' teaching task is heavy, which leads the result that they have no time to take scientific research. The opportunity to apply for the research projects is very few. They have a few opportunities to study professional teaching methods and develop a professional vision. Second, the students practice after study is not enough. We should pay much attention on our goal orientation, subject construction, curriculum system construction, teaching staff construction, experiment room construction, practice teaching and experimental teaching.

\section{The mode of personnel development}

The development of talents training model, teaching plan, the construction of curriculum system and practice teaching system construction, etc were determined by the goal. Since the establishment of department of applied psychology, four times of modifies have been experienced on the personnel training program. After the construction and reform in recent years, we have gradually formed a mode of applied psychology professional talent training mode, as follows: 
First, the goal of talent training

There is one goal of talent training: students should cultivate a good moral character, have the correct outlook on life, world and values, they should have physical and mental health, good personality and personnel of multiple skills. The professional advantages after the students graduate can be in the community, enterprises, education, justice and other departments, they can do psychological consulting, psychological training, management, psychological research and other type of work.

Second, directions of talent training

We present two talent training directions: family and community psychology, human resource management (HRM). The direction of family and community psychology is mainly to cultivate compound talents who can carry out psychological services in family and community. Community and family psychology is concerned with the understanding and application of people's life and aims to improve people's quality of life.

HRM is a function in organizations designed to maximize employee performance in service of an employer's strategic objectives [2]. HRM covers the following core areas: job design and analysis, workforce planning, recruitment and selection,training and development, performance management, remuneration legal issues.[3-4] We typically undertake a number of activities, including employee benefits design, employee recruitment, training and development, performance appraisal, and rewarding (e.g., managing pay and benefit systems).

Third, basic requirements of talent training

From the perspective of humanistic and professional qualities, we put forward three basic requirements for students, the first one is the ability to master various theoretical knowledge and basic skills including psychological investigation, psychological evaluation, psychological counseling and psychological services; the second one is the ability of engaging in business activities, human resources development, family and community mental health service; the third one is the ability to help others enhancing their humanistic qualities and professional qualities.

Forth, changes of talent training

The role of teachers should be guide or inductor; the teaching contents should be positive psychology, instead of the negative psychology; the way of teaching should be changed to goal lead, self exploration, cooperative, discussing and etc; the teaching evaluation should be changed to variety pattern including practices, research reports and papers, examinations, performance; the learning style of students should be changed to various methods including advocated learning, discovery learning.

At present, the construction and development of Applied Psychology specialty in agricultural colleges should focus on the following problems:

\section{First, course construction is the core of professional construction}

Course construction is the core content of the construction of applied psychology. The key construction of the curriculum system is to determine the curriculum arrange, we set main courses as follows: general psychology, experimental psychology, developmental and educational psychology, social psychology, counseling psychology, history of psychology etc.

The training goal has been decomposed into every course and every link of practice to ensure the continuity, systematization and integrity of knowledge. We set general psychology, experimental psychology and psychological statistics and other basic courses in grade one or two. We set counseling psychology, personality psychology, management psychology, consumer psychology, other courses in grade three or four, practice and experimental courses have been put together every 
semester, in order to ensure the consistency and integrity of the system.

The teaching syllabus, teaching materials selection, assessment system, and so on should be established in detail. The syllabus is a guiding document for teaching, psychology syllabus should be emphasized on three aspects: the subject knowledge, the promoted knowledge and ability to solve practical problems.

\section{Second, the construction of teaching staff is the key to professional construction}

At the beginning of the establishment of applied psychology specialty, we only have two assistants, but now we have 10 people, including 1 professor, 4 associate professors, 4 lecturers, 5 of them have doctoral degree. The construction of teachers is the most important in the construction of a new specialty. One method is to introduce and develop a variety of preferential conditions is to attract highly educated, high professional person to work here. Another method is to encourage young teachers to improve themselves and strengthen their teaching basic skills and improve the teachers' ability to implement the modernization of teaching.

In addition, we should also build a part-time teachers system, which is a strong complement to the professional teachers. The part time teachers can be in professional colleges or universities and they also can be in some psychological consulting center. The more important one is to promote the combination and open education with the society.

\section{Third, the construction of laboratory is the material foundation and important guarantee of specialty construction}

To realize the quality of personnel training and the improvement of students' practical ability, it is important that we should have good experiment and practice condition. On the one hand, the laboratory should be equipped with various advanced teaching hardware and software (programming, file system, etc). To solve the problem of insufficient funds and build a platform for other related specialty, maximize and improve the efficiency of resource allocation optimization should be considered. Teachers should make full use of modern educational technology, the practice of teaching content software, experimental equipment and other hardware conditions virtualization. On the other hand, there have rich educational resources in enterprises, scientific research institutes, we should actively and widely joint them in teaching and scientific research, new product development, cooperation, establishment of stable practice base. We should establish a long-term and stable cooperation with other units.

\section{Fourth, the construction of teaching materials is the problem that must be solved in the specialty construction}

The teaching material is the main basis of teachers' teaching and students' learning, and the construction of teaching material is a problem that should be solved in the construction of specialty. We realized that there is a little new knowledge teaching content, a little new research results. We paid too much emphasis on discipline system of knowledge, ignoring the application of knowledge and skills.

So, how should the teachers choose and compile the textbook? First, they should develop new teaching materials according to the training orientation. They can emphasis on classical theory and the depth and breadth of knowledge. In addition, they should try to use high-quality products materials, and even some foreign textbook. In the teaching process, according to the actual situation and characteristics of the university, teaching content should be adjusted. 


\section{Fifth, teaching quality control is the basic requirements of specialty construction}

Teaching quality control is a professional construction. Teaching evaluation can be done after change of the teachers' role, teaching content and methods. Teaching quality control can be done from the perspective of teaching reform, change the way of students' learning. We received good results from the teaching reform, especially in the change of students' learning style, we boldly promote students’ autonomous learning, research learning, and beyond learning.

\section{Summary}

We do have a lot of questions, we seriously have the attitude to improve. We also hope that vigorously support be given to the development of applied psychology specialty, We hope we will become the vanguard applied psychology specialty in Jilin Provincial.

\section{Acknowledgment}

The research reported here was supported by Jilin Higher Education Institute 2015 annual higher education research( JGJX2015D37) and Humanities and Social Sciences in the Twelfth Five-Year Plan project of Education Office in Jilin Province (2015[107]) and general planning project of Ministry of Education Humanities and Social Sciences (12YJAZH211). I am extremely grateful for Ling Xiu's constructive comments on the version of the manuscript.

\section{References}

[1] Z. Zhang. Summary of Applied Psychology Research in the mainland of China in recent ten years. Heilongjiang higher education research, 224(2010) 162-165

[2] P. Johnason, HRM in changing organizational contexts, In: D. G. Collings \& G. Wood (Eds.), Human resource management: A critical approach., London, 2009, pp. 19-37.

[3] D. G.Collings, Wood, G, Human resource management: A critical approach. In: D. G. Collings \& G. Wood (Eds.), Human resource management: A critical approach. London, 2009, pp. 1-16

[4] Buettner, Ricardo. A Systematic Literature Review of Crowdsourcing Research from a Human Resource Management Perspective.48th Annual Hawaii International Conference on System Sciences. Kauai, Hawaii: IEEE. doi:10.13140/2.1.2061.1845. ISBN 978-1-4799-7367-5.

Reference, (2015) 4609-4618 